\title{
Time course of enhanced activity of deoxycytidine kinase and thymidine kinase 1 and 2 in cultured human squamous lung carcinoma cells, $\mathrm{SW}-1573$, induced by $\gamma$-irradiation
}

\author{
J. HAVEMAN ${ }^{1}$, J. SIGMOND ${ }^{2}$, C. VAN BREE ${ }^{1}$, N.A. FRANKEN $^{1}$, C. KOEDOODER ${ }^{1}$ and G.J. PETERS ${ }^{2}$ \\ ${ }^{1}$ Department of Radiotherapy, Academic Medical Center, University of Amsterdam, P.O. Box 22700, 1100 DE Amsterdam; \\ ${ }^{2}$ Department of Medical Oncology, VU University Medical Center, P.O. Box 7057, 1007 MB Amsterdam, The Netherlands
}

Received April 27, 2006; Accepted May 24, 2006

\begin{abstract}
Single high dose rate irradiation of 4 Gy in SW-1573 cells, derived from non-small cell lung cancer, led to increased activities of deoxycytidine kinase $(\mathrm{dCK})$ and thymidine kinase 1 and 2 (TK1 and 2). The activity of dCK increased by approximately $30 \%$ between 1 and $5 \mathrm{~h}$ after irradiation, after which the activity returned to the level of control cells by $8 \mathrm{~h}$ after irradiation. TK1 activity also increased by $30-50 \%$ between 1 and $6 \mathrm{~h}$ after irradiation. The decline to normal levels of dCK concurred with a further increase in the activity of TK1, $8 \mathrm{~h}$ after irradiation. TK2 activity was below control levels during the first $4 \mathrm{~h}$ after irradiation but rose 3 -fold at 8 and $16 \mathrm{~h}$ after treatment. The activities of TK1 and TK2 had returned to approximate control levels $24 \mathrm{~h}$ after irradiation. The observation that mitochondrial TK2 activity increased to a very high level after irradiation may indicate that the activity of this enzyme is not only important for the damage to mitochondrial DNA, the increased activity may also be instrumental for repair of damage to nuclear DNA. We presume that the increase in activity of TK1 after irradiation is limited to cells in S-phase. Recruitment of cells into S-phase, to replace cells killed by irradiation, is probably too slow to offer an explanation for the enhanced activity of TK1 $8 \mathrm{~h}$ after irradiation. The increase in activity of both $\mathrm{dCK}$, and TK1 and 2 might be involved in an adaptive response of the cells to radiation by facilitation of DNA repair. The expression of protein kinase $C$ (PKC) decreased during the first $5 \mathrm{~h}$ after irradiation. At $5 \mathrm{~h}$ after irradiation the level of expression had decreased by $>50 \%$. The decrease in PKC expression is concurrent with the increase in $\mathrm{dCK}$ activity. This suggests a role of PKC in the signal transduction from DNA damage to the increase in activity of enzymes instrumental in DNA repair.
\end{abstract}

Correspondence to: Dr J. Haveman, Department of Radiotherapy, Academic Medical Center, University of Amsterdam, P.O. Box 22700, 1100 DE Amsterdam, The Netherlands

E-mail: j.haveman@amc.uva.nl

Key words: deoxycytidine kinase, thymidine kinase, protein kinase $\mathrm{C}, \gamma$-irradiation, lung carcinoma cells

\section{Introduction}

The sensitivity of cells to ionizing radiation is dependent on the ability and extent of repair of DNA damage. For this repair sufficient supply of deoxynucleotides is essential. Deoxynucleoside kinases, such as deoxycytidine kinase (dCK) and thymidine kinases (TK) play an important role in the supply of deoxynucleotides (1). These enzymes are involved in the salvage and de novo supply of deoxynucleotides required for DNA synthesis. Thymidylate synthase is the only enzyme for de novo synthesis of dTMP (2), while TK catalyzes the salvage of thymidine to dTMP. There are two TKs, the first one, TK1, is localized in the cytosol, and the other, TK2, is localized in the mitochondria (1). As a tightly S-phase correlated enzyme, TK1 is solely present in proliferating cells. TK2 is expressed in proportion to the mitochondrial content of the cells and is not cell cycle regulated (1). In previous studies it is not always clear which subform is referred to, and whether 'total' TK or TK1 is meant. TK1 has strict substrate specificity for thymidine; other deoxynucleosides are not substrates for TK1. However, TK2 has broader substrate specificity and also catalyzes the phosphorylation of deoxycytidine and deoxyuridine. As TK2, dCK is not cell cycle regulated. dCK has broad substrate specificity and catalyzes not only the phosphorylation of deoxycytidine but also that of thymidine, deoxyadenosine and deoxyguanosine. It is obvious that an increased activity of these enzymes can supply the cell with more deoxynucleotides which can increase the ability to repair radiation-induced DNA damage.

Even irradiation at doses below $1 \mathrm{~Gy}$ affects the activity of TK activity in cells from mouse spleen and thymus assayed ex vivo (3). Al-Nabulsi et al (4) observed that rat glioma cells which lack TK expression are more radiosensitive than wildtype cells. The radiosensitivity of the mutant cells lacking TK expression correlated with their inability to repair sublethal damage. After transfection with herpes simplex-TK in the mutant cell line, resistance to radiation was partially restored. In another study, McKenna et al (5), using Friend mouse erythroleukemia cells which were TK-deficient, showed increased sensitivity to cell killing and increased induction of cytogenetic aberrations in the deficient cells after $\gamma$-irradiation as compared to wild-type cells. These findings strongly implicate TK as a major determinant of the radiation response. 
Boothman et al (6) showed that TK-transcripts and TKactivities were elevated after irradiation. Expression of TKmRNA after irradiation was transient and exhibited bellshaped kinetics. Wei et al (7) determined the effect of ionizing irradiation on nine enzymes involved in nucleotide metabolism. Enzymes involved in the purine pathway were hardly affected by radiation, but the activities of TK, thymidylate synthase and $\mathrm{dCK}$ were increased after radiation treatment. The changes in activity were more important in a relatively radiationresistant cell line. These results strongly indicate that the TK, thymidylate synthase and dCK enzymes play important roles in the response of cells to ionizing radiation. In addition to effects with irradiation the deoxynucleoside kinases play an important role in the activation of some widely used nucleoside analogs in the treatment of viral diseases and cancer $(8,9)$. These analogs include arabinosylcytosine (ara-C), gemcitabine, chlorodeoxyadenosine, fludarabine and some dideoxynucleosides.

In earlier experiments we observed a 1.5 - to 2 -fold increase in activity of dCK, TK1 and TK2 $6 \mathrm{~h}$ after pulsed low dose rate irradiation in SW-1573 cells and this correlated with an enhanced cell survival in the initial part (1-6 Gy) of the survival curve (10). We suggested that this enhanced cell survival could be caused by an adaptive response to irradiation. We did not find increased activity $24 \mathrm{~h}$ after low dose rate irradiation. In survival curves obtained after single doses of conventional high dose rate radiation this type of adaptive response is masked at doses higher than $1 \mathrm{~Gy}$. We hypothesized (10) that increased nucleotide supply is related to the adaptive response. In low dose rate experiments irradiation takes several hours and as a result increased activity of dCK or TK may be already initiated during irradiation. Therefore, in the present study we investigated how fast some key enzymes are activated after single dose irradiation at a high dose rate. We measured the levels of activity of both TK1 and 2 and dCK during the first $24 \mathrm{~h}$ after irradiation. In order to obtain some possible clue to the process of activation of the deoxynucleoside kinases, the expression of the pluripotent protein kinase $\mathrm{C}$ was measured in the same period after irradiation.

\section{Materials and methods}

Cell culture. The human squamous lung carcinoma cell line SW-1573 was grown in Leibowitz-15 medium (L15; GibcoBRL life technologies, Breda, The Netherlands) supplemented with $10 \%$ fetal bovine serum and $2 \mathrm{mM}$ glutamine at $37^{\circ} \mathrm{C}$ with no $\mathrm{CO}_{2}$. The doubling time of the SW-1573 cells in exponential growth is 22-24 h (11). For experiments cells were plated in $\varnothing 100$-mm culture dishes $48 \mathrm{~h}$ before irradiation. Cells were irradiated in late exponential growth (with 50$65 \%$ of the cells in G1-phase, $30-40 \%$ in S-phase, $7-15 \%$ in G2-phase as determined by BrdU incorporation).

Irradiation. Irradiation was performed in a ${ }^{137} \mathrm{Cs}$ cabinet at a dose rate of $0.6 \mathrm{~Gy} / \mathrm{min}$. Two ${ }^{137} \mathrm{Cs}$ sources are present in the cabinet, one above and one below the position of the cell culture dishes. The distance between the sources and the dishes with cells was $22.5 \mathrm{~cm}$. Lead filters were used to ensure a homogenous dose in all culture dishes. The dose rate on different positions of dishes was checked using thermoluminescence dosimetry.

Clonogenic assay. Cell survival was determined using the clonogenic assay. In brief, after irradiation cells were trypsinized and plated at appropriate dilutions in 6-well culture plates (Costar). Eight days later the colonies were stained with $0.05 \%(\mathrm{w} / \mathrm{v})$ crystal violet in $6 \%(\mathrm{w} / \mathrm{v})$ glutaraldehyde. Colonies of 50 cells or more were counted as originating from a single clonogenic cell. The plating efficiency of SW-1573 cells was always in the range of $80-100 \%$.

Deoxycytidine kinase (dCK) and thymidine kinase (TK) activity. At different times, up to $24 \mathrm{~h}$, after irradiation cells were harvested. After trypsin treatment the cells were washed two times with PBS, centrifuged and the resulting cell pellets were snap-frozen in liquid nitrogen. The frozen cells were stored at $-80^{\circ} \mathrm{C}$, until analysis. The activity of $\mathrm{dCK}$ was determined essentially as described previously $(12,13)$. In order to measure dCK selectively and bypass thymidine kinase 2 (TK2) mediated phosphorylation of deoxycytidine, we used $\left[8-{ }^{3} \mathrm{H}\right]-$ 2-chlorodeoxyadenosine $\left({ }^{3} \mathrm{H}-\mathrm{CdA}\right)$ as the substrate (14) which is not activated by TK2. Cell pellets were suspended in assay buffer (50 mM Tris-HCL pH 7.6, and $2 \mathrm{mM}$ dithiothreitol) and sonificated. Twenty-five microliters of appropriately diluted supernatant (protein range 0.4-1.2 $\mu \mathrm{g} / \mu \mathrm{l}$ ) was added to a reaction mixture (50 $\mu 1$ total volume) containing (final concentrations) $50 \mu \mathrm{M}{ }^{3} \mathrm{H}-\mathrm{CdA}(5.9 \mathrm{kBq} / \mathrm{nmol}), 50 \mathrm{mM}$ Tris-HCL pH 7.6, 2 mM DTT, 5 mM $\mathrm{MgCl}_{2}, 5 \mathrm{mM}$ ATP and $10 \mathrm{mM}$ sodium fluoride. After incubation (15 and $30 \mathrm{~min}$ ) the reaction was terminated by heating $\left(3 \mathrm{~min}\right.$ at $\left.95^{\circ} \mathrm{C}\right)$. The substrate and the product, 2-chlorodeoxyadenosine monophosphate (CdAMP), were separated by thin layer chromatography on PEI cellulose using distilled water after which radioactivity was measured. Protein concentrations were measured using the standard BioRad Bradford assay (15).

TK1 and TK2 activities were determined as described for dCK, using the 10000-g supernatants prepared with cold TK buffer (50 mM Tris-HCL, $1 \mathrm{mM}$ EDTA, pH 7.4). To $25 \mu 1$ substrate solution $\left(21.9 \mu \mathrm{M}{ }^{14} \mathrm{C}-\mathrm{TdR}\right.$, final specific activity $1.8 \mathrm{Ci} / \mathrm{mmol} ; 20 \mathrm{mM}$ ATP; $10 \mathrm{mM} \mathrm{MgCl}$; $10 \mathrm{mM}$ Tris; $200 \mu \mathrm{M}$ EDTA). Enzyme (25 $\mu \mathrm{l})$ containing supernatant $(0.12-1.0 \mu \mathrm{g}$ protein $/ \mu \mathrm{l})$ or $10 \mu 150 \mathrm{mM}$ dCTP [an excess inhibiting TK2 (16) but not TK1] and $15 \mu 1$ enzyme were added, and incubated at $37^{\circ} \mathrm{C}$. The reaction was stopped by heating the mixture at $95^{\circ} \mathrm{C}$ for $3 \mathrm{~min}$, followed by the addition of $10 \mu 15 \mathrm{mM}$ TdR, $5 \mathrm{mM}$ thymine. Substrate (TdR) and product (TMP) were separated by thin layer chromatography on PEI cellulose layers, with distilled water as eluent. Radioactivity was estimated as described for the dCK enzyme assay.

Western blots. Whole cell proteins ( 25 or $30 \mu \mathrm{g}$ ) were electrophoresed on $12.5 \%$ SDS-polyacrylamide gels and by electroblotting transferred to nitrocellulose membranes (Hybond ECL membranes, Amersham, Buckinghamshire, UK). Blots were blocked overnight in blocking buffer. For dCK the blocking buffer was PBS-T with 5\% BioRad milk powder. Thereafter the first antibody was added: rabbit anti-human dCK polyclonal antibody $(1: 5000 ; 1 \mathrm{~h}$ at room temperature in $1 \%$ BioRad milk powder in PBS-T) (17) and subsequently 


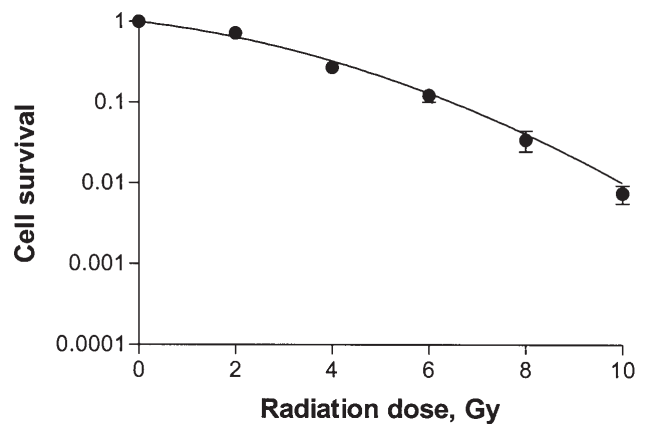

Figure 1. Radiation dose survival curves of SW-1573 cells after irradiation. The data are on clonogenic capacity and represent the mean of at least three experiments. Error bars indicate SEM. In several cases the size of the symbol precluded drawing of the bar.

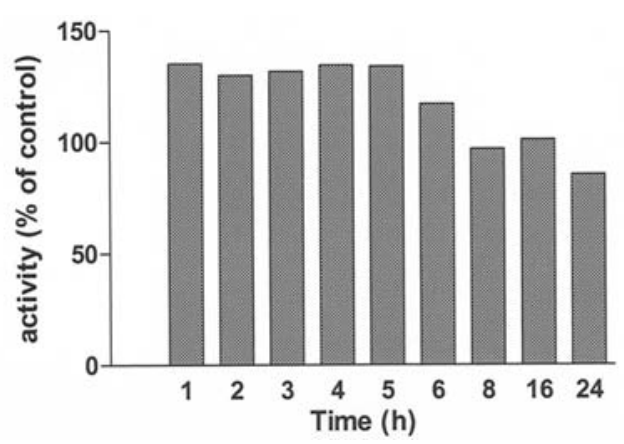

Figure 2. Deoxycytidine kinase (dCK) activity in SW-1573 cells during the period after irradiation with a dose of 4 Gy relative to control cells. The enzyme activity in unirradiated control cells was $4.8 \mathrm{nmol} / \mathrm{h} / \mathrm{mg}$ protein.

the goat anti-rabbit secondary antibody conjugated to horseradish peroxidase $(1: 2500 ; 1 \mathrm{~h}$ at room temperature). For protein kinase $\mathrm{C}$ Western blotting the same protocol was used. The blocking buffer was Protifar (5\%) in PBS-T. Exposure to the first antibody was in $1 \%$ Protifar milk powder in PBS-T (mouse monoclonal against PKC at a dilution of 1:5000). This was than followed by the second antibody (1:1000 anti-mouse) (Santa Cruz Biotechnology). Blots were developed using the ECL Western blot detection kit (Amersham). Blots were scanned using a Versa-Doc 4000 from BioRad and analyzed by means of BioRad software.

\section{Results}

The clonogenic capacity of the SW-1573 cells decreased to approximately $30 \%$ relative to control cells after irradiation at 4 Gy (Fig. 1). This is in agreement with previous results (18). Cells were treated during late exponential growth phase, near confluency ( $>50 \%$ of cells in G1-phase). In non-irradiated cells the level of activity of dCK was $4.8 \mathrm{nmol} / \mathrm{h} / \mathrm{mg}$ protein. Fig. 2 shows the dCK activity in the 24 -h period after irradiation. An approximate $30 \%$ increase in activity is observed during the first $5 \mathrm{~h}$ after irradiation, $8 \mathrm{~h}$ after irradiation the activity had returned to a level not very different from that of unirradiated control cells. We also determined the total amount of dCK in these cells by Western blotting (Fig. 5). The dCK protein content remained constant after irradiation.

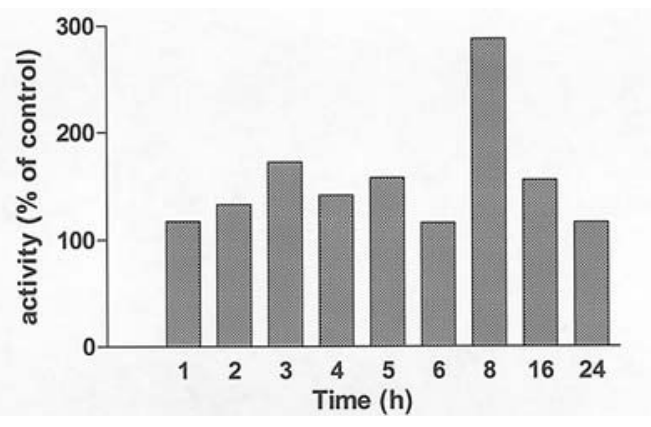

Figure 3. Thymidine kinase-1 (TK1) activity during the period after irradiation of SW-1573 cells relative to control cells. The enzyme activity in unirradiated control cells was $20.0 \mathrm{nmol} / \mathrm{h} / \mathrm{mg}$ protein.

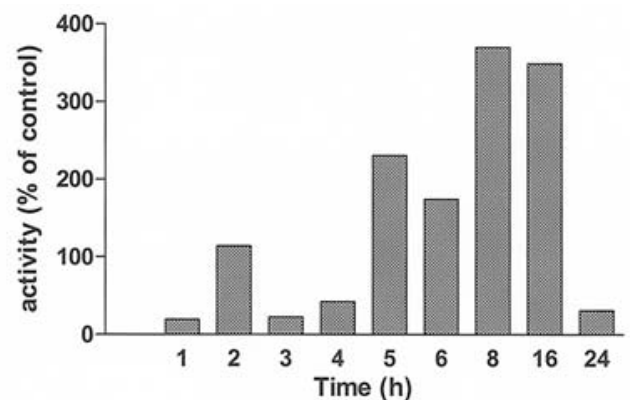

Figure 4. Thymidine kinase-2 (TK2) activity in SW-1573 cells during the period after irradiation with a dose of $4 \mathrm{~Gy}$ relative to control cells. The enzyme activity in unirradiated control cells was $9.4 \mathrm{nmol} / \mathrm{h} / \mathrm{mg}$ protein.

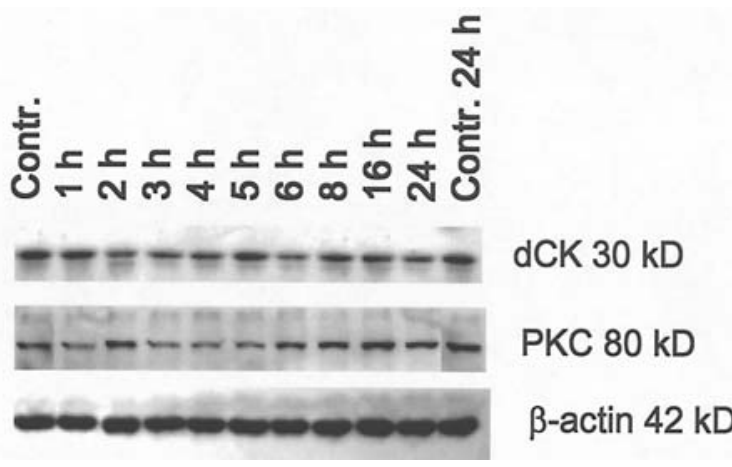

Figure 5. Western blotting of dCK, PKC and B-actin. The cells used came from unirradiated control cultures at two time-points, comparable with cells immediately after or $24 \mathrm{~h}$ after irradiation, and from cell cultures at different time-points after irradiation (4 Gy) as indicated.

In non-irradiated cells the level of activity of TK1 and 2 was 20.0 and $9.4 \mathrm{nmol} / \mathrm{h}$ per $\mathrm{mg}$ protein, respectively. The activity of TK1 in the period after irradiation is shown in Fig. 3 and of TK2 in Fig. 4. The activity of TK1 is elevated some $40 \%$ during the first $6 \mathrm{~h}$ after irradiation and it is elevated $>2$-fold $8 \mathrm{~h}$ after irradiation, but this increased activity had declined 16 and $24 \mathrm{~h}$ after irradiation to a level not very different from that during the first hours after irradiation. TK2 activity during the first $4 \mathrm{~h}$ after irradiation was lower than control cell levels, but rose thereafter. The activity 5 and $6 \mathrm{~h}$ after $4 \mathrm{~Gy}$ had increased to $\sim 2$-fold that of control cells. The increase in activity 8 and $16 \mathrm{~h}$ after treatment was $>3$-fold. 


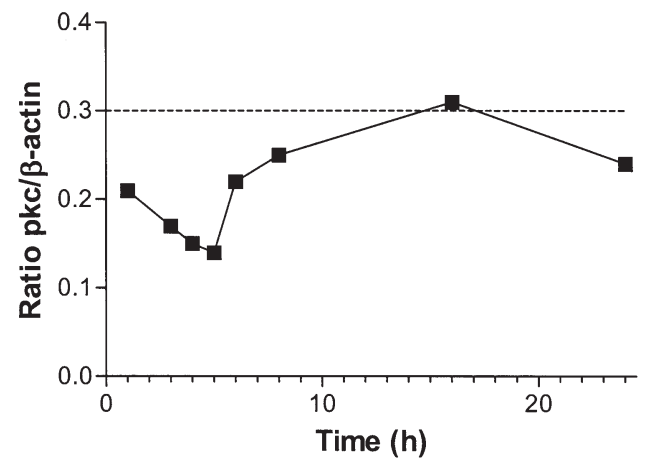

Figure 6. Relative protein kinase $\mathrm{C}$ (PKC) expression in the period after irradiation, data obtained from scans of the blots in Fig. 5. The dashed line represents the level of expression of the enzyme in unirradiated control cells.

At $24 \mathrm{~h}$ after irradiation a decrease in activity of TK2 was observed.

Fig. 5 shows Western blotting of dCK, PKC and $\beta$-actin from the cells harvested at different times after irradiation at 4 Gy. In Fig. 6 the relative expression of protein kinase $C$ compared to $B$-actin after $4 \mathrm{~Gy}$, obtained from this blot, is shown. It is obvious that the expression of this enzyme decreases during the first $5 \mathrm{~h}$ after irradiation. At $5 \mathrm{~h}$ after irradiation the level of expression had decreased $>50 \%$. This decrease is concurrent with the increase in dCK activity.

\section{Discussion}

Our results show that high dose rate irradiation of SW-1573 cells leads to increased activity of the deoxynucleoside kinases $\mathrm{dCK}$, TK1 and 2, as expected. The time course of the increased activity differed. The activity of both $\mathrm{dCK}$ and TK1 increased after $1 \mathrm{~h}$ following radiation, while that of TK2 started to increase after $4 \mathrm{~h}$. However, when dCK activity returned to control levels, the activity of TK1 further increased. Twentyfour hours after irradiation the activities of TK1 and TK2 had returned to approximate control levels.

Cells which lack TK expression are more sensitive to irradiation than cells expressing normal TK levels, implicating a role for TK in the cellular response to radiation $(4,5)$. Boothman et al (6) showed that the levels of TK-mRNA and TK activity increased dose dependently both in normal and tumor cells. The highest level of mRNA was obtained after a single dose of $5 \mathrm{~Gy}$. Peak values in mRNA were observed 1-5 $\mathrm{h}$ after irradiation depending on the cell line studied. Wei et al (7) showed that the activities of TK and dCK increased after irradiation: TK activity was not increased $10 \mathrm{~h}$ after irradiation, but was increased by more than 5 -fold $24 \mathrm{~h}$ after 4 Gy in 'resistant' cells relative to control cells, dCK activity increased $6 \mathrm{~h}$ after irradiation and remained high up to $24 \mathrm{~h}$ after irradiation in 'resistant' cells. Since the increase in enzyme activity was far less in a radiosensitive cell line, it was concluded that both TK and dCK play an important role in the response to irradiation. The results of Wei et al differ from ours in that dCK activity in the 'resistant' cell line was still high $24 \mathrm{~h}$ after irradiation, whereas in our results a decline in activity to normal levels is observed at times longer than $5 \mathrm{~h}$ after irradiation. The results of Csapo et al (19) show that
dCK is activated in approximately $30 \mathrm{~min}$ in human lymphocytes after $\gamma$-irradiation and remained activated for at least $2 \mathrm{~h}$, TK activity was not elevated in their experiments, but the follow-up period after irradiation was only $120 \mathrm{~min}$.

Previously we showed an increase in enzymatic activity of TK1 and 2 as well as of dCK in SW-1573 cells after pulsed low dose rate irradiation (10). We hypothesized that this is part of an adaptive response of the cells to irradiation, which correlates with enhanced survival in the initial part of the survival curve obtained after pulsed low dose rate irradiation. To investigate the kinetics of increase in activity of the enzymes in more detail, the present study was undertaken. From the results it is clear that the increase in enzyme activity is not so rapid as to affect fast components of DNA repair, but the changes that take place during the first 5-6 $\mathrm{h}$ in activities of $\mathrm{dCK}$ are sufficiently fast to influence repair of sublethal damage. The changes in activity of $\mathrm{dCK}$ as well of that of TK2 can affect potentially lethal damage repair. As there is no increase in $\mathrm{dCK}$ protein content, it may be concluded that the changes in activity reflect a post-translational event, at the level of regulation by signal transduction of enzyme activity. An increased activity of dCK after cellular stress seems to be a general phenomenon. Sasvari-Szekely et al (20) and Csapo et al (21) have observed an increase in dCK activity in lymphoid cells after exposure of cells to a variety of drugs, such as the dCK substrates chlorodeoxyadenosine and ara-C, but also unrelated compounds such as $\mathrm{NaF}$, aphidicolin and etoposide. Van den Neste et al (22) observed dCK activation by UV-irradiation in leukemia derived lymphocytes, 1-3 h after irradiation, whereas TK activity did not increase in the first $3 \mathrm{~h}$ after irradiation. This activation was mimicked by $\mathrm{H}_{2} \mathrm{O}_{2}$, counteracted by $\mathrm{N}$-acetylcysteine and completely abolished by the growth factor inhibitor suramin. The authors conclude that the post-translational upregulation might be initiated by a modification that is initiated at the cell surface.

Although it was previously reported that protein kinase $\mathrm{C}$ would activate dCK by phosphorylation (23), more recent evidence does not support this role of protein kinase $\mathrm{C}$ (14). The post-translational regulation might involve protein phosphorylation since incubation of the enzyme with protein phosphatases abolished the activity (21) and protein kinase A catalyzed phosphorylation increased the enzyme activity (14). Staurosporin is a protein kinase C inhibitor and in SW1573 cells it increased dCK activity (24), whereas cortisol decreased the dCK activity in SW-1573 cells (25). However, staurosporine also affects cyclin-dependent kinases which may subsequently interfere with dCK. Other types of modifications and signal transduction might play a role in the stress (drugs, radiation)-induced increase in dCK activity.

The observation that mitochondrial TK2 activity is increased to a very high level after irradiation indicates that the activity of this enzyme is not only important for the damage to mitochondrial DNA. The increased activity may also be instrumental for repair of damage to nuclear DNA. We presume that the increase in activity of TK1 after irradiation is limited to cells in S-phase. Recruitment of cells into S-phase, to replace cells killed by irradiation, is probably too slow to offer an explanation for the enhanced activity of TK1 $8 \mathrm{~h}$ after irradiation. Based on the present results we presume that the increase in activity of both $\mathrm{dCK}$, and TK 1 and 2 is involved in 
an adaptive response of the cells to radiation by quickly facilitating damage repair. Our results on PKC suggest a role of this enzyme in the signal transduction from DNA damage to increased activity of enzymes instrumental for DNA repair. The radiation-induced increase in enzyme activity after irradiation could be beneficial in clinical use in combination with chemotherapy. Several anti-cancer agents are dependent on these enzymes for their activation. For example gemcitabine, a deoxycytidine analog, which is used in the treatment of lung and pancreas cancer is activated by dCK (26) while the pyrimidine analogs 5-fluorodeoxyuridine, 5-bromodeoxyuridine and 5-iododeoxyuridine are activated by TK1 (1). Since these agents are used in combination with radiotherapy in the clinic it might be advantageous to apply these agents during the period of increased enzyme activity induced by radiotherapy treatment instead of before.

\section{Acknowledgements}

Many thanks are due to Mr. H.M. Rodermond and to $\mathrm{Mr}$. W.J.P. Loves for valuable technical assistance.

\section{References}

1. Arner ES and Eriksson S: Mammalian deoxyribonucleoside kinases. Pharmacol Ther 67: 155-186, 1995.

2. Peters GJ and Köhne CH: Fluoropyrimidines as antifolate drugs. In: Anticancer Drug Development Guide: Antifolate Drugs in Cancer Therapy. Jackman AL (ed). Humana Press Inc., Totowa, NJ, pp101-145, 1999.

3. He Q, Skog S, Welander I and Tribukait B: X-irradiation effects on thymidine kinase (TK): I. TK1 and 2 in normal and malignant cells. Cell Prolif 35: 69-81, 2002.

4. Al-Nabulsi I, Takamiya Y, Voloshin Y, Dritschilo A, Martuza RL and Jorgensen TJ: Expression of thymidine kinase is essential to low dose radiation resistance of rat glioma cells. Cancer Res 54: 5614-5617, 1994

5. McKenna PG, McKelvey VJ and Frew TL: Sensitivity to cell killing and the induction of cytogenetic damage following gamma irradiation in wild-type and thymidine kinase-deficient Friend mouse erythroleukaemia cells. Mutat Res 200: 231-242, 1988.

6. Boothman DA, Davis TW and Sahijdak WM: Enhanced expression of thymidine kinase in human cells following ionizing radiation. Int J Radiat Oncol Biol Phys 30: 391-398, 1994.

7. Wei S, Ageron-Blanc A, Petridis F, Beaumatin J, Bonnet S and Luccioni C: Radiation-induced changes in nucleotide metabolism of two colon cancer cell lines with different radiosensitivities. Int J Radiat Biol 75: 1005-1013, 1999.

8. Eriksson S, Kierdaszuk B, Munch-Petersen B, Oberg B and Johansson NG: Comparison of the substrate specificities of human thymidine kinase 1 and 2 and deoxycytidine kinase toward antiviral and cytostatic nucleoside analogs. Biochem Biophys Res Commun 176: 586-592, 1991.

9. Wang J, Choudhury D, Chattopadhyaya J and Eriksson S: Stereoisomeric selectivity of human deoxyribonucleoside kinases. Biochemistry 38: 16993-16999, 1999.

10. Castro Kreder N, van Bree C, Peters GJ, Loves WJ and Haveman J: Enhanced levels of deoxycytidine kinase and thymidine kinase 1 and 2 after pulsed low dose rate irradiation as an adaptive response to radiation. Oncol Rep 9: 141-144, 2002.
11. Haveman J, Rietbroek RC, Geerdink A, van Rijn J and Bakker PJ: Effect of hyperthermia on the cytotoxicity of 2',2'-difluorodeoxycytidine (gemcitabine) in cultured SW1573 cells. Int J Cancer 62: 627-630, 1995.

12. Ruiz van Haperen V, Veerman G, Vermorken JB, Pinedo HM and Peters G: Regulation of phosphorylation of deoxycytidine and 2',2'-difluorodeoxycytidine (gemcitabine); effects of cytidine 5 '-triphosphate and uridine 5'-triphosphate in relation to chemosensitivity for 2',2'-difluorodeoxycytidine. Biochem Pharmacol 51: 911-918, 1996.

13. Bergman AM, Pinedo HM, Jongsma AP, Brouwer M, Ruiz van Haperen V, Veerman G, Leyva A, Eriksson S and Peters GJ: Decreased resistance to gemcitabine $\left(2^{\prime}, 2^{\prime}\right.$-difluorodeoxycytidine) of cytosine arabinoside-resistant myeloblastic murine and rat leukemia cell lines: role of altered activity and substrate specificity of deoxycytidine kinase. Biochem Pharmacol 57: 397-406, 1999.

14. Spasokoukotskaja T, Csapo Z, Sasvari-Szekely M, Virga S, Talianidis I, Eriksson S and Staub M: Effect of phosphorylation on deoxycytidine kinase activity. Adv Exp Med Biol 486: 281-285, 2000.

15. Bradford MM: A rapid and sensitive method for the quantitation of microgram quantities of protein utilizing the principle of protein-dye binding. Anal Biochem 72: 248-254, 1976.

16. Munch-Petersen B, Cloos L, Tyrsted G and Eriksson S: Diverging substrate specificity of pure human thymidine kinases 1 and 2 against antiviral dideoxynucleosides. J Biol Chem 266: 9032-9038, 1991.

17. Van der Wilt CL, Kroep JR, Loves WJ, Rots MG, van Groeningen CJ, Kaspers GJ and Peters GJ: Expression of deoxycytidine kinase in leukaemic cells compared with solid tumour cell lines, liver metastases and normal liver. Eur J Cancer 39: 691-697, 2003.

18. Castro Kreder N, van Bree C, Franken NA and Haveman J: Colour junctions as predictors of radiosensitivity: X-irradiation combined with gemcitabine in a lung carcinoma cell line. J Cancer Res Clin Oncol 129: 597-603, 2003.

19. Csapo Z, Keszler G, Safrany G, Spasokoukotskaja T, Talianidis I, Staub M and Sasvari-Szekely M: Activation of deoxycytidine kinase by gamma-irradiation and inactivation by hyperosmotic shock in human lymphocytes. Biochem Pharmacol 65: 2031-2039, 2003.

20. Sasvari-Szekely M, Spasokoukotskaja T, Szoke M, Csapo Z, Turi A, Szanto I, Eriksson S and Staub M: Activation of deoxycytidine kinase during inhibition of DNA synthesis by 2chloro-2'-deoxyadenosine (Cladribine) in human lymphocytes. Biochem Pharmacol 56: 1175-1179, 1998.

21. Csapo Z, Sasvari-Szekely M, Spasokoukotskaja T, Talianidis I, Eriksson S and Staub M: Activation of deoxycytidine kinase by inhibition of DNA synthesis in human lymphocytes. Biochem Pharmacol 61: 191-197, 2001.

22. Van den Neste E, Smal C, Cardoen S, Delacauw A, Frankard J, Ferrant A, van den Berghe $\mathrm{G}$ and Bontemps F: Activation of deoxycytidine kinase by UV-C-irradiation in chronic lymphocytic leukemia B-lymphocytes. Biochem Pharmacol 65: 573-580, 2003.

23. Wang LM and Kucera GL: Deoxycytidine kinase is phosphorylated in vitro by protein kinase $\mathrm{C}$ alpha. Biochim Biophys Acta 1224: 161-167, 1994.

24. Van der Wilt CL, Kroep JR, Bergman AM, Loves WJ, Alvarez E, Talianidis I, Eriksson S, van Groeningen CJ, Pinedo HM and Peters GJ: The role of deoxycytidine kinase in gemcitabine cytotoxicity. Adv Exp Med Biol 486: 287-290, 2000.

25. Bergman AM, Pinedo HM and Peters GJ: Steroids affect collateral sensitivity to gemcitabine of multidrug-resistant human lung cancer cells. Eur J Pharmacol 416: 19-24, 2001.

26. Ruiz van Haperen V and Peters GJ: New targets for pyrimidine antimetabolites for the treatment of solid tumours. 2: Deoxycytidine kinase. Pharm World Sci 16: 104-112, 1994. 